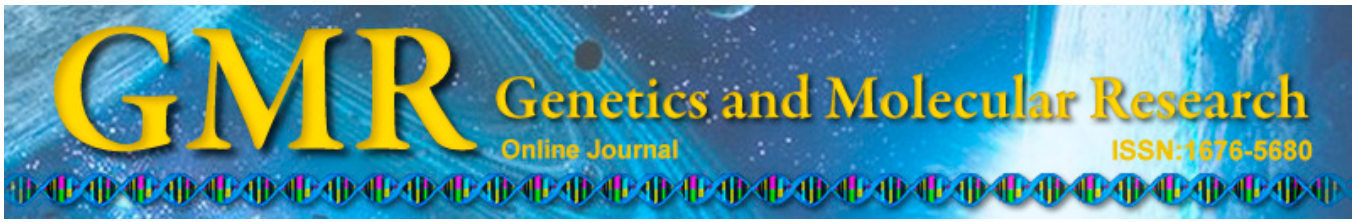

\title{
Karyotype of Philodryas nattereri and Philodryas olfersii with a comparative analysis of the Dipsadidae family
}

\author{
M.D.A. Nery ${ }^{1}$, M.A.O. Alves ${ }^{1}$, H.D. Aquino ${ }^{1}$, E.A. Nery ${ }^{2}$, L.B.M. Bezerra ${ }^{3}$, \\ R.T.M. Ribeiro ${ }^{4}$ and H.S.A. Monteiro ${ }^{5}$ \\ ${ }^{1}$ Departamento de Biologia, Centro de Ciências, \\ Universidade Federal do Ceará, Fortaleza, CE, Brasil \\ ${ }^{2}$ Hospital Geral de Fortaleza, Fortaleza, CE, Brasil \\ ${ }^{3}$ Hospital de Messejana, Fortaleza, CE, Brasil \\ ${ }^{4}$ Instituto de Biociências, Universidade de São Paulo, São Paulo, SP, Brasil \\ ${ }^{5}$ Departamento de Fisiologia e Farmacologia, Faculdade de Medicina, \\ Universidade Federal do Ceará, Fortaleza, CE, Brasil \\ Corresponding author: M.D.A. Nery \\ E-mail: marinetes@ufc.br
}

Genet. Mol. Res. 14 (2): 6297-6302 (2015)

Received July 28, 2014

Accepted February 6, 2015

Published June 11, 2015

DOI http://dx.doi.org/10.4238/2015.June.11.3

\begin{abstract}
Cytogenetic studies of Philodryas nattereri and Philodryas olfersii revealed a diploid chromosome number $2 \mathrm{n}=36$ for both species ( 3 metacentrics, 4 submetacentrics, and 10 acrocentrics, with a fundamental number of 51 and 52, respectively). The results obtained are novel and similar to those previously described for species belonging to the Dipsadidae family. The conventional karyotype is also novel and divergent from other species of the Dipsadidae family, where a higher proportion of macrochromosomes predominate, revealing two distinct groups in this family. The data are reported and discussed considering the cytotaxonomy of the family. These results strongly support the current view that chromosomal alterations, such as centric fusion and Robertsonian's translocations, seems to support the distinct
\end{abstract}


importance of chromosomal rearrangements in speciation within this group.

Key words: Chromosome number; Cytotaxonomy; Dipsadidae; Philodryas

\section{INTRODUCTION}

The New World Dipsadidae are one of the largest radiations of colubroidean snakes, with approximately 700 species distributed throughout the Americas and the West Indies (Hedges et al., 2009; Zaher et al., 2009). Recent studies (Vidal et al., 2000, 2010; Pinou et al., 2004; He et al., 2009; Zaher et al., 2009) confirm three historically distinct lineages (Cadle, 1984).

Chromosome studies among Dipsadidae family snakes are limited to a few taxa, with chromosome numbers ranging from $2 \mathrm{n}=24$ to 56 or more (Beçak and Beçak, 1969; Ferrarezi, 1994). The increase in the number of chromosomes is accompanied by an increase in morphological derivations (Oguiura et al., 2009).

The basic chromosome number among Philodryas genera is considered to be $2 \mathrm{n}=36$, consisting of a karyotype with 16 macrochromosomes and 20 microchromosomes, which is relatively common in most species of this genus (Moreno et al., 1987). In this genus, the chromosomes are almost identical pair by pair in their relative lengths and centromeric indices. The only difference is in the stages of differentiation of the $\mathrm{W}$ chromosome: these may differ from the $\mathrm{Z}$ chromosome by the centromere position or by size or by both (Beçak and Beçak, 1969; Singh, 1972; Beçak et al., 1990).

Philodryas nattereri and Philodryas olfersii have both been identified as having a diploid chromosome number $2 \mathrm{n}=36$ (Beçak and Beçak, 1969), but there are no studies that describe other karyotypical parameters, such as a fundamental number (FN), C-banding, NOR, and karyotype differentiation, between species of the Dipsadidae family.

The aim of the present study was to describe the karyotypic parameters of the cosmopolitan species $P$. nattereri and $P$. olfersii from northeastern Brazilian. In addition, karyotype differentiation in the Dipsadidae family is discussed.

\section{MATERIAL AND METHODS}

\section{Sampling}

Six snakes of each species (P. nattereri and P. olfersii) were captured on Aroeiras Farm in the municipality of Upanema $\left(5^{\circ} 38^{\prime} 32^{\prime \prime} \mathrm{S}\right.$ and $\left.37^{\circ} 15^{\prime} 27^{\prime \prime} \mathrm{W}\right)$, State of Rio Grande do Norte, and transported to NUROF-UFC. The animals were maintained in individual cages with water ad libitum and fed with $15 \mathrm{~g}$ mice every 30 days until chromosome analysis.

\section{Mitotic stimulation and cell culture}

Snake peripheral blood lymphocytes were cultured under standard conditions at $37^{\circ} \mathrm{C}$ for $72 \mathrm{~h}$ in RPMI-1640 medium, supplemented with $10 \%$ calf fetal serum. Colchicine was added at a concentration of $1 \times 10^{6} \mathrm{M}$. Cultures grown without an intercalator were used as 
controls. Hypotonic treatment of preparations $(10 \mathrm{~mL} \mathrm{KCl}, 0.075 \mathrm{mM})$ was carried out for 40 min at $37^{\circ} \mathrm{C}$. The cells were fixed in a 3:1 methanol:acetic acid mixture and dropped on wet, cooled slides (Seabright, 1972).

\section{Chromosome, FN, and karyotype description}

Cell suspensions were transferred onto a microscopy glass slide and covered with a $60^{\circ} \mathrm{C}$ water film, set to dry at room temperature, and then stained with phosphate-buffered Giemsa, $\mathrm{pH} 6.8,(5 \%)$ for $25 \mathrm{~min}$. The metaphases resulting in ideal spreading and chromosome contraction were photomicrographed. Diploid chromosome number (2n) and FN were determined through direct counts of chromosomes and their arms, respectively. Chromosome types (metacentric, submetacentric, acrocentric, and telocentric) were identified following the method of Levan et al. (1964).

The chromosome data for $P$. nattereri and $P$. olfersii were compared with available data from other species of the Dipsadidae family (Table 1). A karyotypic parameter matrix was built, including the somatic chromosome number (2n), the FN, and the chromosomal formula. This matrix was analyzed through PC-ORD 6.0 (McCune and Mefford, 2011) to produce a UPGMA cluster based on the Bray-Curtis similarity index.

\section{RESULTS AND DISCUSSION}

\section{Determination of the chromosome numbers of $P$. nattereri and $P$. olfersii}

As shown in Figures 1 and 2, the chromosome number for both P. nattereri and $P$. olfersii was $2 \mathrm{n}=36$. This number agrees with those previously reported for the genus Philodryas (Beçak et al., 1966; Beçak and Beçak, 1969; Moreno et al., 1987).
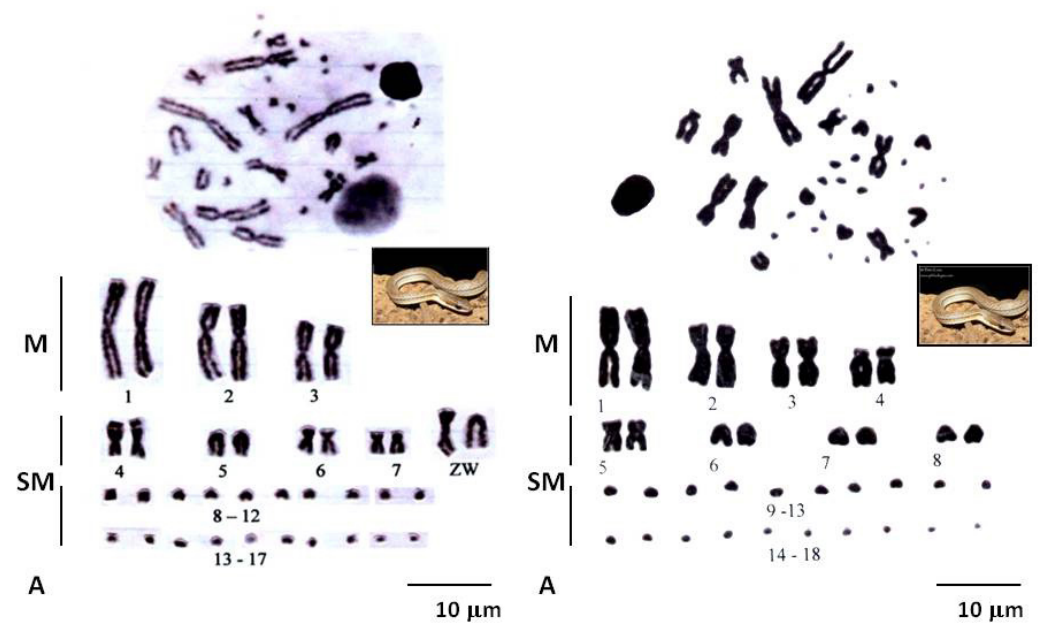

Figure 1. Metaphase of cells from female and male Philodryas nattereri with $2 \mathrm{n}=36$ chromosomes, respectively. Karyotype with 16 macrochromosomes and 20 microchromosomes bearing secondary constriction in the fifth pair of metacentric macrochromosomes. $\mathrm{M}=$ metacentric; $\mathrm{SM}=$ submetacentric; $\mathrm{A}=$ acrocentric. 


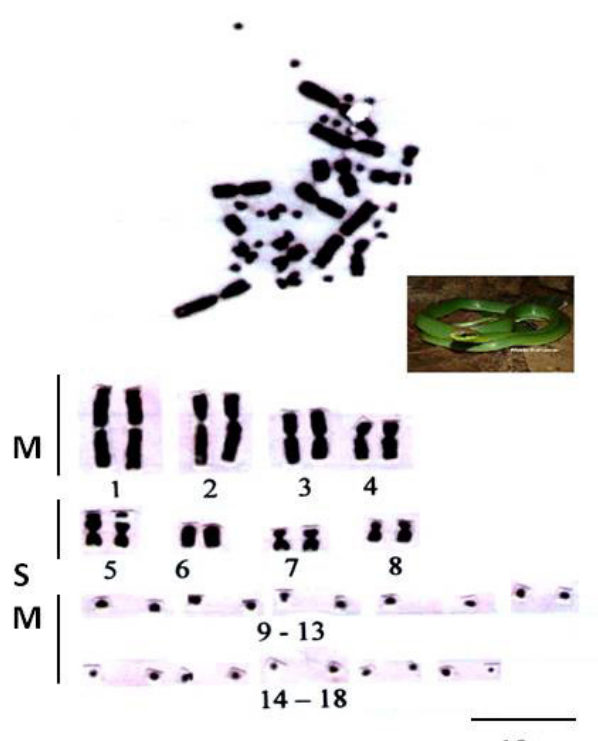

A

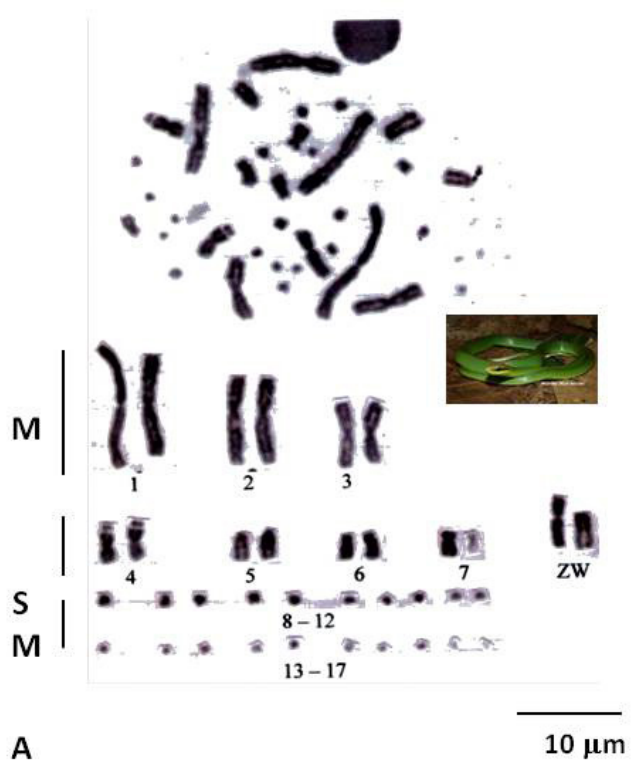

$10 \mu \mathrm{m}$

Figure 2. Metaphase of cells from female and male Philodryas olfersii with $2 \mathrm{n}=36$ chromosomes, respectively. Karyotype with 16 macrochromosomes and 20 microchromosomes bearing secondary constriction in the fifth pair of metacentric macrochromosomes. $\mathrm{M}=$ metacentric; $\mathrm{SM}=$ submetacentric; $\mathrm{A}=$ acrocentric.

No significant differences were observed between karyotypes of males and females analyzed. Thus, there was no heteromorphism related to the sex chromosome. The karyotype of female P. nattereri included 3 pairs of metacentric, 4 pairs of submetacentric, 10 pairs of acrocentric chromosomes, and the sexual chromosomes $\mathrm{Z}$ and $\mathrm{W}$ were submetacentric and acrocentric, respectively. The karyotype of male $P$. nattereri included 4 pairs of metacentric, 4 pairs of submetacentric, and 10 pairs of acrocentric chromosomes. The resulting FN was 51 and 52 for females and males, respectively.

In P. olfersii, the karyotype included 3 pairs of metacentric, 4 pair of submetacentric, and 10 pairs of acrocentric chromosomes, and the sexual chromosomes $\mathrm{Z}$ and $\mathrm{W}$ were metacentric and submetacentric, respectively. The resulting FN was 52 for females and males. The macrochromosomes (metacentric and submetacentric) showed the presence of secondary constriction in the fifth pair of metacentric chromosomes.

Some Philodryas species show secondary constriction in chromosome pair 5 (Beçak et al., 1971). As $P$. chamissonis exhibits NOR in the long arm of chromosome pair 2, it was proposed that translocation of insertion types may be accounted for by polymorphisms in this genus (Moreno et al., 1987).

The similarity analysis of 24 species of the family Dipsadidae based on karyotypic parameters (Figure 3) revealed two distinct groups with similarities greater than 50\%. Group A, including Hydrodynastes bicinctus, Hydrodynastes gigas, Leimadophis almadensis, and Xenodon severus, presented lower FN (40 to 42) due to a higher proportion of microchromosomes (acrocentric), therefore, representing a trend towards symmetry. In group $\mathrm{B}$, which includes $P$. nattereri and $P$. olfersii, a higher $\mathrm{FN}$ was presented in relation to group A because of the presence of a higher number of macrochromosomes (metacentric, submetacentric, telocentric) (Table 1). 


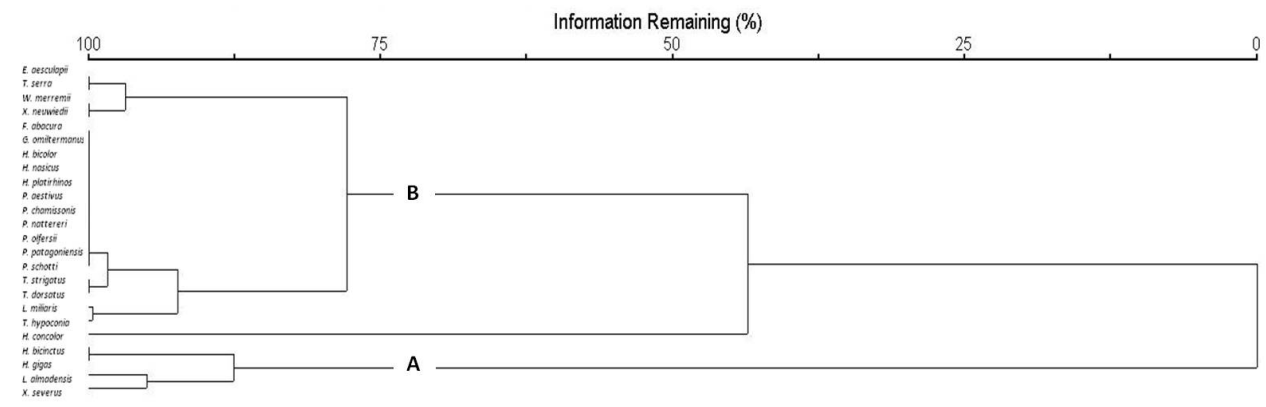

Figure 3. Bray-Curtis similarity dendrogram based on a matrix of karyotypical data. A. Group with predominantly symmetrical karyotypes. B. Group with asymmetrical karyotypes.

Table 1. Karyotypic parameters of 24 species of the Dipsadidae family.

\begin{tabular}{|c|c|c|c|c|}
\hline Species & $2 n$ & $\mathrm{FN}$ & Karyotype & Reference \\
\hline Erythrolamprus aesculapii & 28 & 48 & $16 \mathrm{M}+4 \mathrm{SM}+8 \mathrm{~A}$ & Beçak and Beçak, 1969 \\
\hline Farancia abacura & 36 & 52 & $14 \mathrm{M}+2 \mathrm{SM}+20 \mathrm{~A}$ & Camper and Hanks, 1995 \\
\hline Geophis omiltermanus & 36 & 52 & $14 \mathrm{M}+2 \mathrm{SM}+20 \mathrm{~A}$ & Hardy, 1976 \\
\hline Helicops bicolour & 36 & 52 & $16 \mathrm{M}+20 \mathrm{~A}$ & De Smet, 1978 \\
\hline Heterodon nasicus & 36 & 52 & $16 \mathrm{M}+20 \mathrm{~A}$ & Baker et al., 1972 \\
\hline Heterodon platirhinos & 36 & 52 & $16 \mathrm{M}+20 \mathrm{~A}$ & Baker et al., 1972 \\
\hline Hydrodynastes bicinctus & 24 & 40 & $16 \mathrm{M}+8 \mathrm{~A}$ & Beçak and Beçak, 1969 \\
\hline Hydrodynastes gigas & 24 & 40 & $16 \mathrm{M}+8 \mathrm{~A}$ & Beçak and Beçak, 1969 \\
\hline Hydromorphus concolor & 46 & 62 & $12 \mathrm{M}+4 \mathrm{SM}+30 \mathrm{~A} / 11 \mathrm{M}+5 \mathrm{SM}+30 \mathrm{~A} / \mathrm{ZW}$ & Solorzano et al., 1989 \\
\hline Liophis almadensis & 28 & 42 & $16 \mathrm{M}+12 \mathrm{~A}$ & Benirschke and Hsu, 1975 \\
\hline Liophis miliaris & 28 & 55 & $27 \mathrm{M}+1 \mathrm{~A}$ & Beçak and Beçak, 1969 \\
\hline Philodryas aestivus & 36 & 52 & $12 \mathrm{M}+18 \mathrm{SM}+20 \mathrm{~A} / \mathrm{ZW}$ & Beçak and Beçak, 1969 \\
\hline Philodryas chamissonis & 36 & 52 & $14 \mathrm{M}+18 \mathrm{SM}+20 \mathrm{~A} / \mathrm{ZW}$ & Moreno et al., 1987 \\
\hline Philodryas nattereri & 36 & 51 & $\begin{array}{l}16 \mathrm{M}+16 \mathrm{SM}+20 \mathrm{~A} \\
12 \mathrm{M}+18 \mathrm{SM}+21 \mathrm{~A} / \mathrm{ZW}\end{array}$ & Present study \\
\hline Philodryas olfersii & 36 & 52 & $\begin{array}{l}14 \mathrm{M}+18 \mathrm{SM}+20 \mathrm{~A} \\
13 \mathrm{M}+3 \mathrm{SM}+20 / \mathrm{WW}\end{array}$ & Present study \\
\hline Philodryas patagoniensis & 36 & 52 & $\begin{array}{l}12 \mathrm{M}+4 \mathrm{SM}+20 \mathrm{~A} \\
11 \mathrm{M}+5 \mathrm{SM}+20 \mathrm{~A} / \mathrm{ZW}\end{array}$ & Beçak and Beçak, 1969 \\
\hline Philodryas schotti & 36 & 52 & & Beçak et al., 1966 \\
\hline Thamnodynastes hypoconia & 34 & 54 & $\begin{array}{l}12 \mathrm{M}+8 \mathrm{SM}+14 \mathrm{~A} \\
11 \mathrm{M}+9 \mathrm{SM}+14 \mathrm{~A} / \mathrm{ZW}\end{array}$ & Beçak and Beçak, 1969 \\
\hline Thamnodynastes strigatus & 32 & 50 & $\begin{array}{l}14 \mathrm{M}+4 \mathrm{SM}+14 \mathrm{~A} \\
13 \mathrm{M}+5 \mathrm{SM}+14 \mathrm{~A} / \mathrm{ZW}\end{array}$ & Beçak and Beçak, 1969 \\
\hline Tropidodryas serra & 28 & 48 & $16 \mathrm{M}+4 \mathrm{SM}+8 \mathrm{~A} / \mathrm{ZW}$ & Beçak and Beçak, 1969 \\
\hline Tomodon dorsatus & 32 & 50 & $14 \mathrm{M}+4 \mathrm{SM}+14 \mathrm{~A} / \mathrm{ZW}$ & Beçak and Beçak, 1969 \\
\hline Waglerophis merremii & 30 & 46 & $16 \mathrm{M}+14 \mathrm{~A} / \mathrm{ZW}$ & Bianchi et al., 1969 \\
\hline Xenodon neuwiedii & 30 & 46 & $14 \mathrm{M}+2 \mathrm{SM}+14 \mathrm{~A} / \mathrm{ZW}$ & Beçak and Beçak, 1969 \\
\hline Xenodon severus & 30 & 44 & $14 \mathrm{M}+16 \mathrm{~A}$ & Beçak et al., 1971 \\
\hline
\end{tabular}

$2 \mathrm{n}=$ diploid chromosome number; $\mathrm{FN}=$ fundamental number.

The observation of clustering based on similarities of a karyotype parameter (FN) (Figure 3) is in strong disagreement with recent Dipsadidae molecular phylogeny (Grazziotin et al., 2012) and seems to support the distinct importance of chromosomal rearrangements during speciation within this group.

\section{ACKNOWLEDGMENTS}

The authors would like to acknowledge the support of Centro de Ciências and Departamento de Fisiologia e Farmacologia, from Universidade Federal do Ceará during this study. 


\section{REFERENCES}

Baker RJ, Mengden GA and Bull JJ (1972). Karyotypic studies of thirty-eight species of North American snakes. Copeia 1972: 257-265.

Beçak ML, Beçak W, Roberts FL, Shoffner RN, et al. (1971). Chromosome Atlas: Fish, amphibians, reptiles and birds. 1 st edn. Springer Verlag, Berlin.

Beçak ML, Rabello-Gay NN, Beçak W, Soma M, et al. (1990). The W chromosome during the evolution and in sex abnormalities of snakes, DNA content, $\mathrm{C}$ banding. In: Cytogenetics of amphibians and reptiles (Olmo E, ed.). Birkhauser Verlag, Basel.

Beçak W and Beçak ML (1969). Cytotaxonomy and chromosomal evolution in Serpentes. Cytogenetics 8: 247-262.

Beçak W, Beçak ML and Nazareth HRS (1966). Evolution and sex chromosomes in Serpentes. Mem. Inst. Butantan. 33: 151-152.

Benirschke K and Hsu TC (1975). Chromosome Atlas: Fish, Amphibians, Reptiles and Birds. 2nd edn. Springer Verlag, Berlin.

Bianchi NO, Beçak W, De Bianchi MS, Beçak ML, et al. (1969). Chromosome replication in four species of snakes. Chromosoma 26: 188-200.

Cadle JE (1984). Molecular systematics of neotropical xenodontine snakes: I. South American xenodontines. Herpetologica 40: 8-20.

Camper JD and Hanks B (1995). Variation in the nucleolus organizer region among New World snakes. J. Herpetol. 29: 468-471.

De Smet WHO (1978). A comparison of the electrophoretic haemoglobin patterns of the vertebrates. Acta Zool. Pathol. 70: $119-131$.

Ferrarezzi H (1994). Uma sinopse dos gêneros e classificação de serpentes (Squamata): I. Scolephidia e Alethinophidia nas colubrideos. Herpetologia no Brasil 1: 69-80.

Grazziotin FG, Zaher H, Murphy RW, Scrocchi G, et al. (2012). Molecular phylogeny of the New World Dipsadidae (Serpentes: Colubroidea): a reappraisal. Cladistics 28: 437-459.

Hardy LM (1976). The chromosomes of a rare Mexican colubrid snake. Copeia 1976: 189-191.

He M, Feng JC, Liu SY, Guo P, et al. (2009). The phylogenetic position of Thermophis (Serpentes: Colubridae), an endemic snake from the Qinghai-Xizang plateau, China. J. Nat. Hist. 43: 479-488.

Hedges SB, Couloux A and Vidal N (2009). Molecular phylogeny, classification, and biogeography of West Indian racer snakes of the tribe Alsophiini (Squamata, Dipsadidae, Xenodontinae). Zootaxa 2067: 1-28.

Levan A, Fredga K and Sandberg AA (1964). Nomenclature for centromeric position on chromosomes. Hereditas 52: 201-220.

McCune B and Mefford MJ (2011). PC-ORD. Multivariate Analysis of Ecological Data. Available at [http://www.pcord. com/pcordwin.htm]. Accessed April 3, 2014.

Moreno R, Navarro J, Iturra P and Veloso AM (1987). The karyotype of Philodryas chamissonis (Colubridae): Identification of nucleolar organizer region (NOR) and sex chromosomes by banding methods. Braz. J. Genet. 3: 497-506.

Oguiura N, Collares MA, Furtado MFD, Ferrarezzi H, et al. (2009). Intraspecific variation of the crotamine and crotasin genes in Crotalus durissus rattlesnakes. Gene 446: 35-40.

Pinou T, Vicario S, Marschner M, and Caccone A (2004). Relict snakes of North America and their relationships within Caenophidia, using likelihood-based Bayesian methods on mitochondrial sequences. Mol. Phylogenet. Evol. 32: 563-574.

Seabright M (1972). The use of proteolytic enzymes for mapping of structural rearrangements in the chromosome of man. Chromosoma 36: 204-210.

Singh L (1972). Evolution of karyotypes of snakes. Chromosoma 38: 185-236.

Solórzano A, Gutiérrez JM and Cerdas L (1989). Notes on the natural history and karyotype of the colubrid snake, Hydromorphus concolor Peters, from Costa Rica. J. Herpetol. 23: 314-315.

Vidal N, Kindl SG, Wong A and Hedges SB (2000). Phylogenetic relationships of Xenodontine snakes inferred from 12S and 16S ribosomal RNA sequences. Mol. Phylogenet. Evol. 14: 389-402.

Vidal N, Dewynter M and Gower DJ (2010). Dissecting the major American snake radiation: a molecular phylogeny of the Dipsadidae Bonaparte (Serpentes, Caenophidia). C. R. Biol. 333: 48-55.

Zaher H, Grazziotin FG, Cadle JE, Murphy RW, et al. (2009). Molecular phylogeny of advanced snakes (Serpentes, Caenophidia) with an emphasis on South American Xenodontines: a revised classification and descriptions of new taxa. Pap. Avulsos Zool. 49: 115-153. 